\title{
Epidemics in Schools*
}

\begin{abstract}
$\mathrm{T}$ HIS volume constitutes an interim report of a committee appointed by the Medical Research Council seven years ago to investigate the subject of epidemic and other illnesses in schools from both the scientific and practical points of view. Of the schools investigated, twenty were public schools for boys and seventeen for girls, the majority of the pupils being boarders, and the social class being very similar in both. Most of the pupils had been to preparatory schools, so that there was no sudden change in environment-from the family to schooland were between thirteen and eighteen years of age. The criterion of sickness adopted was that causing at least one day's absence from school.

The following are some of the points that emerge from the enormous amount of data collected and analysed. Nasopharyngeal infections from the attack rates seemed to be more prevalent among the girls; but this is apparently not because girls are more susceptible than boys, but because the girls are subjected to stricter surveillance. The common cold was one of the most important causes of lost time, and if influenza is included, making one group of "nasopharyngeal infection", accounts for as much as 53 per cent among girls, and 43 per cent among boys, of all time lost on account of minor respiratory * Epidemics in Schools : an Analysis of the Data collected during
the First Five Years of a Statistical Inquiry by the School Epidemics the First Five Years of a Statistical Inquiry by the School Epidemics Committee. (Privy Council : Medical Research Council, Special Report
Series, No. 227.) Pp. ii + 289. (London: H.M. Stationery Office, 1938.) 4s. 6 d. net.
\end{abstract}

troubles. Epidemic influenza was almost confined to the Lent term, and many other diseases showed a tendency to be concentrated into this term. The incidence of injuries was heaviest among boys in the Christmas term; but whether this is due to intensified activity as a result of good health, or to more football in this term, is uncertain. Boys suffer twice as frequently from middle ear disease, two and a half times as frequently from pneumonia, and eleven times as frequently from acute rheumatism, compared with girls. There is no evidence as to the cause of this greater incidence upon boys; it may be a real sex difference, but it may in part be due to the fact that girls are under stricter supervision. More than half the boys and half the girls had had their tonsils removed, but there is no evidence that wholesale tonsillectomy results in a diminished incidence of nasopharyngeal and some other diseases.

In regard to the apparent relation between herpes zoster and chicken pox, it is of interest that in eighteen out of twenty occasions when zoster preceded chicken pox, the first case of chicken pox might, from the point of view of time, have been infected from a case of zoster.

Dr. Lempriere contributes an interesting historical introduction on the medical history of public schools, and Dr. Griffith a section on the bacteriology of otitis media and mastoid disease, pneumonia and streptococcal infections, with determinations of the types of micro-organisms present in these infections.

\section{Work of the Forestry Commissioners}

$\mathrm{P}$ ERHAPS the most interesting part of the eighteenth annual report of the Forestry Commissioners for the year ending September 30, 1937 (London: H.M. Stationery Office. 1s. net), is the account of the work undertaken to give effect to the Government policy for the Special Areas in connexion with afforestation. In the previous annual report (to September 1936) reference was made to the initiation of a scheme of afforestation and forest workers' hold. ings in the Special Areas of England and Wales. It was then pointed out that both the acquisition of the necessary land and the provision of plants would take time, so that no large scheme of afforestation could be anticipated during the present year.

The scheme proposed envisaged the acquisition of 100,000 acres of plantable land, its afforestation and the formation of 500 forest workers' holdings in three years. This proposal was regarded as an experimental step which, if successful, would be followed by a larger scheme covering 200,000 acres and 1,000 holdings to be put through in ten years.

At the close of the year under review, 568,000 acres were examined in or within a $15 \cdot$ mile radius of the Special Areas, namely, 225,000 in the Northern Area (Durham, Tyneside, Haltwhistle and West Cumberland) and 343,000 in the South Wales Area. Of this area, 72,000 acres in the north and 80,000 acres in South Wales were found to be subject to rights of common and so not available for the purpose in view. On the whole, owners of land were favourable to the scheme. By the end of the year, 42,900 acres of plantable land had been acquired spread in nearly equal amounts between the two regions.

Nursery work had to be considerably extended and a large new nursery has been established at Tair Onen in the neighbourhood of Cardiff. At this nursery no less than seventeen forest workers' holdings have been established. Although probably but little known to the public, this side of the activities of the Commission is by no means the least interesting, for the work has been brought to a high level of efficiency.

Owing to a shortage of plants it was not found possible to carry out the additional planting work either during the season of 1936-37 or that of 1937-38; in the latter year the projected programme of 3,350 acres being reduced to 3,000 acres. It is added : "Except for any ill-effects due to the prolonged drought of the spring of 1938, plant supply should not in future be a limiting factor". It is to be feared that in some parts of the country at least there will have been a considerable mortality, both on 